\title{
Spot urinary albumin creatinine ratio as a predictor of preeclampsia and dilemma in clinical interpretation
}

\author{
L. Thulasi Devi', Anurag Ravi Nimonkar ${ }^{2 *}$
}

\author{
${ }^{1}$ Department of Obstetrics and Gynecology, Military Hospital, Amritsar, Punjab, India \\ ${ }^{2}$ Department of Computer Science Engineering, SRMIST, KTK, Chennai, Tamil Nadu, India
}

Received: 27 July 2018

Accepted: 28 August 2018

\section{*Correspondence:}

Mr. Anurag Ravi Nimonkar,

E-mail: anuragnimonkar@gmail.com

Copyright: (c) the author(s), publisher and licensee Medip Academy. This is an open-access article distributed under the terms of the Creative Commons Attribution Non-Commercial License, which permits unrestricted non-commercial use, distribution, and reproduction in any medium, provided the original work is properly cited.

\begin{abstract}
Background: The objective of this study was to evaluate the efficacy of spot urinary albumin creatinine ratio (UACR) as a predictor of preeclampsia and dilemma faced by clinicians in interpretation of lab values expressed in different units, lack of standardization and its further ramifications in long term follow up and prevention of complications of preeclampsia. Wide variation for estimation of UACR leads to confusion in practice guidelines and its interpretation as single International practical information regarding laboratory measurements, calculation, reporting and interpretation doesn't exist. This prospective randomized study was conducted in Out Patient Department of Obstetrics and Gynaecology in a tertiary care hospital over a period of 1 year after due clearance was obtained from Ethical Committee.

Methods: This was prospective study involving 400 ladies reporting for Outpatient ANC services within the given time period as per existing guidelines at a tertiary care hospital. Patients were assessed at first booking visit at 18-20 weeks, and thereafter based on clinical and haematological findings, severity of disease more frequently if desired and were admitted in case of imminent eclampsia. The mean age of the patients was $20.5 \pm 0.5$ and $24.5 \pm 0.5$ years and treatment duration were till successful delivery and 06 weeks postpartum for persistent microalbuminuria and exclusion of underlying medical cause for Hypertension. Fetomaternal morbidity and mortality was not a criterion of exclusion.

Results: Compared with 24-hour urinary protein excretion, the spot UACR may be a simple, convenient, and accurate indicator of significant proteinuria and future complications in women with preeclampsia with proper and intensive clinical follow up and intervention to prevent feto maternal morbidity and mortality. A strong correlation was evident between spot UACR with high sensitivity and specificity.

Conclusions: UACR measurement is a simple, quick, and reasonably reliable method for prediction and assessment of severity of preeclampsia. Spot UACR correlates better than spot UPCR to 24-hour urinary protein excretion to the severity of disease and as predictor of severity of disease.
\end{abstract}

Keywords: Clinical interpretation, Predictor, Preeclampsia, UACR

\section{INTRODUCTION}

Hypertensive disorders complicate $5 \%$ to $10 \%$ of all pregnancies and are associated with significant maternal morbidity and mortality. ${ }^{1,2}$ The latest analysis by the
World Health Organization suggests that, in developed countries, $16 \%$ of maternal deaths in pregnancy were a result of hypertensive disorders. ${ }^{2}$ In women presenting with elevations in BP in the latter half of pregnancy (defined as a sustained elevation in blood pressure of 
$\geq 140 \mathrm{~mm} \mathrm{Hg}$ systolic and/or $\geq 90 \mathrm{~mm} \mathrm{Hg}$ diastolic), detailed laboratory evaluations are essential to determine whether a patient has a diagnosis of preeclampsia. Measurement of protein excretion in a 24-hour urine collection has been the longstanding gold standard for the quantitative evaluation of proteinuria in pregnancy. 24hour urine collection is time consuming, inconvenient, and not always reliable because of the difficulty in collecting the sample correctly. An alternative method for quantitative evaluation of proteinuria is the measurement of the spot Urinary albumin: creatinine ratio (UACR), which avoids the influence of variations in urinary solute concentration and provides a more convenient and rapid method as predictor for risk of developing preeclampsia. Till date, prediction of preeclampsia and its preventive therapy has remained a challenge to practicing obstetricians. If it is possible to predict the development of preeclampsia, appropriate monitoring can ensue as well as some evidence to support the prophylactic benefit of early introduction of aspirin, calcium and possibly heparin in high-risk prothrombotic conditions can be obtained. ${ }^{3-5}$

The pathophysiological event resulting in preeclampsia begins early in pregnancy and precedes the onset of clinical features. ${ }^{6}$ Most important pathophysiological hallmark is endothelial cell damage and abnormal placentation. $^{6,7}$ Microalbuminuria is a marker of endothelial dysfunction and can be used as an early marker of endothelial dysfunction of preeclampsia and overt proteinuria is preceded by a microalbuminuric phase. Although 24-h collection of urine is the gold standard for quantifying urine albumin excretion, it is cumbersome and results in delay of at least $24 \mathrm{~h}$ in diagnosis. ${ }^{8,9}$ Therefore, the spot urinary albumin-tocreatinine ratio (UACR) has been advocated as an easy alternative. ${ }^{89}$ Microalbuminuria is currently defined as a urinary albumin excretion (UAE) of 30 to $300 \mathrm{mg} / 24$ hours, if measured in a 24-hour urine collection, as urinary albumin excretion rate (AER) of 20 to 200 $\mu \mathrm{g} / \mathrm{min}$, if measured in a timed urine collection, or of 30 to $300 \mathrm{mg} / \mathrm{g}$, if measured with the use of the urinary albumin: creatinine ratio (UACR) in a spot urine collection. $^{10}$ Measurement of a spot urine albumin concentration (UAC) only, without simultaneously measuring urine creatinine, is somewhat less expensive but susceptible to variation as a result of variation in urine concentration due to hydration and other factors. ${ }^{11}$
This study is aimed at evaluation of subjective and objective statistical benefits and prevention of morbidity and feto-maternal mortality by early detection of preeclampsia in early second trimester by a simple spot UACR, its proper interpretation and more frequent clinical, haematological and biochemical surveillance by accurate interpretation by clinicians.

\section{METHODS}

This prospective observational study was conducted between January 2017 to December 2017 and a total of 400 women in booking and second trimester pregnancy who met the inclusion criteria were enrolled in a tertiary care teaching hospital. Primary outcome was determined by development of clinical signs of preeclampsia, eclampsia, gestational hypertension, HELLP syndrome and post-partum eclampsia, or maternal morbidity and mortality including dialysis or any other previously unexplained organ system involvement. Secondary outcome measures were FGR (unexplained), Preterm Delivery, Abruptio, IUFD, Benign proteinuria, GDM, persistent post-partum hypertension and proteinuria.

\section{Data analysis}

In present laboratory urinary albumin and creatinine concentrations are measured as $(\mathrm{mg} / \mathrm{dl})$. ACR is reported in $(\mathrm{mg} / \mathrm{g})$. Albumin concentration in spot urine sample is reported as UAC (mg/L) and in 24-hour urine is reported as UAE (mg/24 hours). Urinary albumin excretion rate in timed urine is expressed as AER $(\mu \mathrm{g} / \mathrm{min})$.

Calculation (UACR): It is ratio of urinary albumin to urinary creatinine; expressed as milligram of albumin excreted per gram of urinary creatinine.

UACR $(\mathrm{mg} / \mathrm{g})=$ Albumin $(\mathrm{mg} / \mathrm{dl}) /$ Creatinine $(\mathrm{mg} / \mathrm{dl}) \times$ 1000

ACR $(\mathrm{mg} / \mathrm{g})$ can be calculated by albumin $(\mathrm{mg} / \mathrm{dl}) \div$ creatinine (g/dl).

Albumin (protein): creatinine ratio: This is simple ratio of albumin or protein to creatinine in urine unlike ACR $(\mathrm{mg} / \mathrm{g})$. For this calculation both albumin and creatinine are in the same unit. Mostly used for assessment of proteinuria rather than albuminuria. Sometimes protein: creatinine ratio is also used.

ACR (simple ratio) = Albumin $(\mathrm{mg} / \mathrm{dl}) /$ Creatinine $(\mathrm{mg} / \mathrm{dl})$.

Table 1: Cut off values indicating normo-albuminuria, microalbuminuria and macroalbuminuria.

\begin{tabular}{|c|c|c|c|c|}
\hline Terms & $\begin{array}{l}\text { 24-hour urine UAE } \\
\text { (mg/24 hours) }\end{array}$ & $\begin{array}{l}\text { Timed overnight urine } \\
\text { AER ( } \mu \mathrm{g} / \mathrm{min})\end{array}$ & $\begin{array}{l}\text { Spot sample } \\
\text { UAC (mg/L) }\end{array}$ & $\begin{array}{l}\text { Spot sample } \\
\text { ACR }(\mathrm{mg} / \mathrm{g}) *\end{array}$ \\
\hline Normo-albuminuria & $<30$ & $<20$ & $<20$ & $<30$ \\
\hline Microalbuminuria & 30 to 300 & 20 to 200 & 20 to 200 & 30 to 300 \\
\hline Macroalbuminuria & $>300$ & $>200$ & $>200$ & $>300$ \\
\hline
\end{tabular}

*ACR (mg/g) values are for both males and females (gender independent). ${ }^{8,12,13}$ 


\section{Inclusion criteria}

Age > 18 years, Haemoglobin > 10gm $\%$, well informed written consent, confirmed singleton pregnancy, spontaneous conception, normotensive and Euglycemic.

\section{Exclusion criteria}

Age <18 years, anaemia, lack of consent, IVF/ART pregnancy, multiple Gestation, known cardiovascular, hepatic or renal pathology, morbid obesity, overt hypertension, pregestational diabetes, h/o BOH/RPL, thrombophilia, mental retardation, fetal anomaly or IUFD, dehydration, exercise, fever, DM, MCTD, h/o of drug intake, thyroid or other autoimmune disorders.

\section{Study methodology}

400 pregnant women between 18 and 20 weeks of POG, were given a sterile glass urine container without preservative and after instruction a midstream urinary sample was collected. Routine microscopic and spot UACR was calculated. Participants were then followed until delivery.

\section{Sample collection}

For routine testing, fresh urine collected from midstream is preferable. Albumin is stable in urine stored at $2-8{ }^{\circ} \mathrm{C}$ for 7 days. ${ }^{14}$ Precipitates often form in refrigerated or frozen urine, and their fallacious results on albumin measurement have not been thoroughly investigated. Precipitates disappear when the urine is warmed for analysis. Centrifugation of turbid urine is to remove insoluble precipitate before measurement. Long term storage of urine samples at temperatures above $-80{ }^{\circ} \mathrm{C}$ and lower than $-20{ }^{\circ} \mathrm{C}$, produces false negative and low values of albumin concentration. ${ }^{15}$ Albumin is reported to adsorb to plastic surfaces. The allowable sample storage time is unknown. Freezing at $-20{ }^{\circ} \mathrm{C}$ is known to be unsatisfactory. Storage below $-70{ }^{\circ} \mathrm{C}$ is recommended when the measurement cannot be performed promptly, but this is impractical in clinical practice. ${ }^{16}$ Because of variability in urinary albumin excretion, two of the three specimens collected within a 3 to 6-month period should be abnormal before diagnosis of microalbuminuria. Exercise within 24 hours, infection, fever, congestive heart failure, marked hyperglycaemia, marked hypertension, pyuria, and hematuria may elevate urinary albumin excretion over baseline values. ${ }^{17}$

Units of measurements: The units of measurement for UACR were as $\mathrm{mg} / \mathrm{gm}$ or $\mathrm{mg} / \mathrm{mmol}$ or both.

Interconversion of units: UACR $(1 \mathrm{mg} / \mathrm{g}=1 \mu \mathrm{g} / \mathrm{mg}=$ $0.113 \mathrm{mg} / \mathrm{mmol}$ ). Dividing the UACR by 8.84 converts the units (from $\mu \mathrm{g} / \mathrm{mg}$ or $\mathrm{mg} / \mathrm{g}$ to $\mathrm{mg} / \mathrm{mmol}$ ). Easy calculators for conversion are available as mobile applications for easy interpretation by clinicians.

\section{RESULTS}

After obtaining informed consent 400 women were enrolled during reporting between 11 and 20 weeks POG. At the time of booking systolic and diastolic BP were below normal for unaffected group which can be explained by routine second trimester fall in BP; which is not seen in women with predisposition to Preeclampsia.

Age of affected women was in between 24 to 35 years, BP varied greatly in among each group. Diagnosis of severe disease was clinical and POG at diagnosis and delivery varied greatly for each group after assessment of risk benefit ratio.

Antihypertensives and antiplatelet agents were administered on domiciliary basis to the mild PE group and those with severe PE and other biochemical markers of severe disease were managed on inpatient basis for more frequent and intensive monitoring with Doppler studies and more frequent biochemical assessment for aggravation of disease. $\mathrm{MgSO}_{4}$ was administered to all with severe PE, HELLP, and imminent eclampsia as per institutional protocol of Sibai Guidelines. Birth weight of women with severe PE was lower possibly because of prematurity and chronic placental insufficiency.

Authors had one maternal mortality who was on regular follow up and had no clinical signs of severe PE, except for high spot UACR who developed HELLP, eclampsia, ESRD and succumbed to the disease. She was delivered by $\mathrm{CS}$ as she had uncontrolled seizures. Neonate survived with Birth weight of $1.2 \mathrm{~kg}$ at appx 30 weeks POG which is normal for the POG.

All patients with IUFD are included in mild PE and overlap of findings such as FGR with Oligohydramnios and mild PE is inevitable and is part of the clinical spectrum of disease.

All patients were also kept on Doppler surveillance and findings were correlated clinically; however, the Doppler findings and its correlation with spot UACR was beyond the scope of this study.

BP and development of Oligohydramnios, FGR and IUFD cannot be correlated; however, their UACR was more than the cut off value of this observational study. $(12.27 \mathrm{mg} / \mathrm{g})$. Patients with uncomplicated GDM did not develop significant increase in spot UACR, hence correlation was difficult. Patients with overt DM and requiring Insulin were not included in the study to avoid error in correlation to hypertensive disorders of pregnancy alone. 
Table 2: Demographic variables with primary outcome measures $(n=400)$.

\begin{tabular}{|c|c|c|c|c|c|}
\hline Variables & $\begin{array}{l}\text { Unaffected } \\
(\mathrm{n}=248)\end{array}$ & $\begin{array}{l}\mathrm{GH}^{*} \\
(\mathrm{n}=56)\end{array}$ & $\begin{array}{l}\text { Mild PE } \\
(\mathrm{n}=44)\end{array}$ & $\begin{array}{l}\text { Severe PE } \\
(\mathrm{n}=18)\end{array}$ & $\begin{array}{l}\text { HELLP and } \mathrm{MM}^{\#} \\
\left.\left(\mathrm{n}=1^{(}\right)^{(}\right)\end{array}$ \\
\hline Age (years) & $26(21-28)$ & $26(22-27)$ & $31(24-32)$ & $24(20-35)$ & 29 \\
\hline \multicolumn{6}{|l|}{ Gravida (n\%) } \\
\hline Primi & 91 & 2 & 2 & 4 & 0 \\
\hline $\mathrm{G}_{2}$ & 84 & 6 & 6 & 1 & 1 \\
\hline $\mathrm{G}_{3}$ & 86 & 5 & 6 & 1 & 0 \\
\hline $\mathrm{G}_{4}$ & 88 & 6 & 4 & 0 & 0 \\
\hline $\mathrm{G}_{5}$ & 82 & 8 & 2 & 4 & 0 \\
\hline Eclampsia & 0 & 0 & 0 & 2 & $\begin{array}{l}\text { With uncontrolled } \\
\text { eclampsia }\end{array}$ \\
\hline $\begin{array}{l}\mathrm{BP}(\mathrm{mmHg}) \\
\text { systolic }\end{array}$ & $112(102-122)$ & $128(110-132)$ & $132(110-144)$ & $166(142-188)$ & 210 \\
\hline $\begin{array}{l}\mathrm{BP}(\mathrm{mmHg}) \\
\text { diastolic }\end{array}$ & $68(66-74)$ & $78(76-84)$ & $84(80-92)$ & $102(98-118)$ & 180 \\
\hline $\mathrm{POG}^{\wedge}$ at diagnosis & NA & $36^{ \pm 6}(36.4 \pm 1.8)$ & $35^{ \pm 1}(34.6 \pm 1.2)$ & $33^{ \pm 1}(32.4 \pm 4.8)$ & $30^{ \pm 1}$ \\
\hline POG at delivery & $39^{ \pm 6}$ & $39^{ \pm 1}(38.1 \pm 1.2)$ & $38^{ \pm 2}(37.2 \pm 1.4)$ & $36^{ \pm 1}(35.3 \pm 1.5)$ & $30^{ \pm 1}$ \\
\hline $\begin{array}{l}\text { Mode of } \\
\text { delivery } \\
\text { (n\%) }\end{array}$ & No drugs & No drugs & $\begin{array}{l}\text { POG extended till } \\
36 \text { weeks with } \\
\text { Antihypertensives } \\
\text { Aspirin }\end{array}$ & $\begin{array}{l}\mathrm{MgSO}_{4}(\text { Sibai) } \\
\text { Antihypertensives }\end{array}$ & $\begin{array}{l}\mathrm{MgSO}_{4}(\text { Sibai) } \\
\text { Antihypertensives } \\
\text { AED', FFP", } \text { CRYO?, PRP }^{\sim}\end{array}$ \\
\hline Vaginal & 78 & 79 & 72 & 76 & 0 \\
\hline $\mathrm{CS}^{\%}$ & 22 & 21 & 28 & 24 & 1 \\
\hline $\begin{array}{l}\text { Baby weight } \\
\text { (in kg) }\end{array}$ & $3.1(2.7-3.6)$ & $3.0(2.8-3.4)$ & $2.8(2.8-3.0)$ & $1.82(1.4-2.2)$ & 1.2 \\
\hline
\end{tabular}

Table 3: Demographic variables with secondary outcome measures $(n=400)$.

\begin{tabular}{|c|c|c|c|}
\hline Variables & GDM $^{\&}(n=22)$ & OLIGO! and FGR ${ }^{ \pm}(\mathrm{n}=12)$ & IUFD`Abruptio (n=3) \\
\hline Age (years) & $32(28-34)$ & $29(28-35)$ & $33(33-35)$ \\
\hline \multicolumn{4}{|l|}{ Gravida (n\%) } \\
\hline Primi & 0 & 0 & 0 \\
\hline $\mathrm{G}_{2}$ & 1 & 1 & 0 \\
\hline $\mathrm{G}_{3}$ & 2 & 1 & 1 \\
\hline $\mathrm{G}_{4}$ & 2 & 1 & 1 \\
\hline $\mathrm{G}_{5}$ & 3 & 2 & 1 \\
\hline Eclampsia & 0 & 0 & 0 \\
\hline $\mathrm{BP}(\mathrm{mmHg})$ systolic & $122(112-128)$ & $106(100-120)$ & $134(130-156)$ \\
\hline $\mathrm{BP}(\mathrm{mmHg})$ diastolic & $76(74-82)$ & $66(64-72)$ & $96(88-102)$ \\
\hline $\mathrm{POG}^{\wedge}$ at diagnosis & $29^{ \pm 1}(28.6 \pm 2.4)$ & $31^{ \pm 1}(30.4 \pm 1.8)$ & $30^{ \pm 6}(30.2 \pm 1.2)$ \\
\hline POG at delivery & $38^{ \pm 4}(37.6 \pm 1.9)$ & $32^{ \pm 6}(31.6 \pm 2.9)$ & $31^{ \pm 2}(31 \pm 1.8)$ \\
\hline Mode of delivery (n\%) & Only OHA arm included & $\begin{array}{l}\text { All normotensives } \\
\text { Aspirin }\end{array}$ & $\begin{array}{l}\text { All had mild PE on antihypertensives } \\
\text { and Aspirin }\end{array}$ \\
\hline Vaginal & 76 & 42 & 3 \\
\hline $\mathrm{CS}^{\%}$ & 24 & 58 & 0 \\
\hline Baby weight (in $\mathrm{kg}$ ) & $3.4(3.2-3.9)$ & $1.6(1.2-1.9)$ & $1.1(1.0 \pm 0.5)$ \\
\hline
\end{tabular}

\& Gestational Diabetes Mellitus, ! Oligohydramnios, + Fetal Growth Restriction, > Intra Uterine Fetal Demise.

Spot UACR values were increased in affected patients considered under primary outcome of the study and were statistically significant in all groups.
Spot UACR values were increased in affected patients considered under secondary outcome of the study and were statistically significant only in oligohydramnios, 
FGR, IUFD and Abruptio. However statistically significant increase in spot UACR could not be demonstrated in patients with GDM uncomplicated with hypertension.

Table 4: Spot UACR in affected patients (primary outcome).

\begin{tabular}{|c|c|c|c|c|}
\hline & Mild PE $(n=44)$ & Severe PE $(n=18)$ & HELLP and MM (n=1) & $(\mathbf{P})$ \\
\hline UACR $(\mathrm{mg} / \mathrm{g})$ & $0.35-986.68$ & $16.78-2894.66$ & 1608.6 & $\mathrm{P}<0.001$ \\
\hline
\end{tabular}

Table 5: Spot UACR in affected patients (secondary outcome).

\begin{tabular}{lccc} 
& GDM $(\mathrm{n}=22)$ & OLIGO and FGR $(\mathrm{n}=12)$ & IUFD Abruptio $(\mathrm{n}=\mathbf{3})$ \\
$\mathrm{UACR}(\mathrm{mg} / \mathrm{g})$ & $0.6-55.22(\mathrm{P}>0.1)$ & $134.32-2686.34(\mathrm{P}<0.001)$ & $1006.6-1808.2(\mathrm{P}<0.001)$ \\
\hline Statistically significant at $\mathrm{P}<0.05$ &
\end{tabular}

Statistically significant at $\mathrm{P}<0.05$

\section{DISCUSSION}

Preeclampsia remains a leading cause of maternal and foetal morbidity and mortality. ${ }^{18}$ Studies have shown that alteration in and inadequate second wave of cytotrophoblastic invasion in HPE of placenta, endothelial dysfunction has been demonstrated as early as 18 weeks and levels of antiangiogenic factors starts rising as early as 14 weeks of gestation, resulting in high risk for preeclampsia. Microalbuminuria, a marker of endothelial dysfunction, is also apparent by this time. In present study, authors found that spot UACR at 18-20 weeks of gestation was significantly higher in women who developed preeclampsia and FGR with increased morbidity. Although 24-hour collection of urine is the gold standard for quantifying urinary albumin, a spot UACR was used to assess its usefulness as screening test in daily clinical practice. In one study, it was found that the logarithmic conversion of UACR at 11-13 weeks of gestation helped to predict preeclampsia. ${ }^{19,20}$ Spot UACR measurement is performed by many laboratory techniques and continuous improvement in its accuracy improves PPV, sensitivity and specificity. This may be recommended as a routine investigation at 11-13 weeks where logarithmic interpretation may be required and at 18-20 weeks along with anomalies scan to predict high risk gravidas and exhibit preventive therapy as per laid down institutional guidelines like Aspirin, LMWH or high dose of Calcium. These ladies may be followed up more regularly for early subtle clinical signs of preeclampsia, HELLP syndrome, imminent eclampsia or alteration in biochemical parameters by senior obstetrician and an early intervention may be planned to minimize feto maternal morbidity and mortality.

US National Kidney Foundation has recommended that spot urine samples rather than 24-hour urine collections be used to detect and monitor proteinuria in both children and adults. ${ }^{21}$ However recommendations have not been made with regards to pregnancy even in the latest ACOG practice bulletin. Consideration should be given to replacing 24-hour urine collections for protein excretion with spot ACR in the evaluation of women with suspected preeclampsia. The spot simple ACR and spot UACR have been well studied and used. The Australasian Society for the Study of Hypertension in Pregnancy and the International Society for the Study of Hypertension in Pregnancy have proposed the use of the spot UACR as an alternative to $24 \mathrm{~h}$ urine collection, spot UACR is not widely used for the diagnosis or screening of proteinuria in pregnant women with hypertension or as a predictor of preeclampsia. ${ }^{22-26}$

Limitations of this study are number of patients in this study group was small. Larger study groups with RCT and more statistically significant tests may be applied for reliable study outcome. Long term follow up of patients is required.

\section{CONCLUSION}

A spot UACR of more than $12.27 \mathrm{mg} / \mathrm{g}(1.39 \mathrm{mg} / \mathrm{mmol})$ of creatinine between 18 and 20 weeks of POG can predict the development of preeclampsia in pregnancy; however additional studies and cost-benefit analysis are required to confirm these finding before recommending this test for screening purposes.

A strong correlation is evident between the spot UACR and 24-hour urinary protein excretion $(\mathrm{P}<0.001)$. The optimal spot UACR value was $202.82 \mathrm{mg} / \mathrm{g}$ $(22.92 \mathrm{mg} / \mathrm{mmol}$ ) for $0.3 \mathrm{~g} / 24 \mathrm{~h}$ of protein excretion (mild preeclampsia) with a sensitivity and specificity of $>80 \%$ and $>99.5 \%$ respectively for UACR, and $1381.24 \mathrm{mg} / \mathrm{g}$ $(156.08 \mathrm{mg} / \mathrm{mmol})$ for $2 \mathrm{~g} / 24 \mathrm{~h}$ of protein excretion (severe preeclampsia) with a sensitivity and specificity of $>91 \%$ and $>99.5 \%$ respectively.

In present study, it was shown that UACR is significantly higher in patients with severe preeclampsia, FGR, Oligohydramnios, Abruptio, IUFD, HELLP and eclampsia than those with a mild form of the disease. It can be concluded from this study to calculate the cut-off value for UACR for the enrolled patients, above which, a 
severe form of the disease might be predicted after appropriate large population-based RCT. Finally, a better diagnostic potential for UACR than a 24-h urine protein, was suggested based on present result analysis. In conclusion, UACR measurement is a simple, quick, and reasonably reliable method for prediction and assessment of severity of preeclampsia. Authors would also like to add that spot UACR correlates better than spot UPCR to $24 \mathrm{hr}$ urinary protein excretion to the severity of disease and as predictor of severity of disease.

\section{Funding: No funding sources}

Conflict of interest: None declared

Ethical approval: The study was approved by the Institutional Ethics Committee

\section{REFERENCES}

1. Martin JA, Hamilton BE, Sutton PD, Ventura SJ, Mathews TJ, Osterman MJ. Births: final data for 2008. Natl Vital Stat Rep. 2010;59(1):3-71.

2. Khan KS, Wojdyla D, Say L, Gülmezoglu AM, Van Look PF. WHO analysis of causes of maternal death: a systematic review. Lancet. 2006;367:1066-74.

3. Villa PM, Kajantie E, Ra "ikko“nen K, Pesonen AK, Hämäläinen E, Vainio $M$, et al. Aspirin in the prevention of pre-eclampsia in high-risk women. BJOG. 2013;120(6):773.

4. Poon LC, Nicolaides KH. Early prediction of preeclampsia. Obstet Gynecol Int. 2014;2014:297397.

5. Thangaratinam S, Langenveld J, Mol BW, Khan KS. Prediction and primary prevention of pre-eclampsia. Best Pract Res Clin Obstet Gynaecol. 2011;25(4):419-33.

6. Torrado J, Farro I, Zócalo Y, Farro F, Sosa C, Scasso $\mathrm{S}$, et al. Preeclampsia is associated with increased central aortic pressure, elastic arteries stiffness and wave reflections, and resting and recruitable endothelial dys-function. Int J Hypertens. 2015;2015:720683.

7. Ohkuchi A, Hirashima C, Takahashi K, Suzuki H, Matsubara S. Prediction and prevention of hypertensive disorders of pregnancy. Hypertens Res. 2017;40(1):5.

8. Fagerstrom P, Sallsten G, Akerstrom M, Haraldsson B, Barregard L. Urinary albumin excretion in healthy adults: a cross sectional study of 24-hour versus timed overnight samples and impact of GFR and other personal characteristics. BMC Nephrol. 2015;16:8.

9. Huang Q, Gao Y, Yu Y, Wang W, Wang S, Zhong M. Urinary spot albumin: creatinine ratio for documenting proteinuria in women with preeclampsia. Rev Obstet Gynecol. 2012;5(1):9-15.

10. Sarafidis PA, Riehle J, Bogojevic Z, Basta E, Chugh A, Bakris GL. A comparative evaluation of various methods for microalbuminuria screening. Am J Nephrol. 2008;28(2):324-9.
11. American Diabetic Association: Standards of medical care in diabetes-2009. Diabetes Care. 2009;32(suppl 1):S13-61.

12. Levey AS, Coresh J, Balk E, Kausz AT, Levin A, Steffes MW, et al; National Kidney Foundation. National Kidney Foundation practice guidelines for chronic kidney disease: evaluation, classification, and stratification. Ann Intern Med. 2003;139(2):13747.

13. Halimi JM, Hadjadj S, Aboyans V, Allaert FA, Artigou JY, Beaufils M, et al. Microalbuminuria and urinary albumin excretion: French clinical practice guidelines. Diabetes Metabo. 2007;33(4):303-9.

14. Osberg I, Chase HP, Garg SK, DeAndrea A, Harris $\mathrm{S}$, Hamilton $\mathrm{R}$, et al. Effects of storage time and temperature on measurement of small concentrations of albumin in urine. Clin Chem. 1990;36(8):1428-30.

15. Brinkman JW, de Zeeuw D, Duker JJ, Gansevoort RT, Kema IP, Hillege HL, et al. Falsely low urinary albumin concentrations after prolonged frozen storage of urine samples. Clin Chem. 2005;51(11):2181-3.

16. Miller WG, Bruns DE. Laboratory issues in measuring and reporting urine albumin. Nephrol Dial Transplant. 2009;24(3):717-8.

17. Molitch ME, DeFronzo RA, Franz MJ, Keane WF, Mogensen CE, Parving HH, et al. American Diabetes Association: Nephropathy in diabetes. Diabetes Care. 2004;27(suppl 1):S79-83.

18. Townsend R, O'Brien P, Khalil A. Current best practice in the management of hypertensive disorders in pregnancy. Integr Blood Press Control. 2016;9:7994.

19. Papanna R, Mann LK, Kouides RW, Glantz JC. Protein/creatinine ratio in preeclampsia: a systematic review. Obstet Gynecol. 2008;112:135-44.

20. Côté AM, Brown MA, Lam E, von Dadelszen P, Firoz T, Liston RM, et al. Diagnostic accu-racy of urinary spot protein: creatinine ratio for pro-teinuria in hypertensive pregnant women: systematic review. BMJ. 2008;336:1003-6.

21. National Kidney Foundation. K/DOQI clinical practice guidelines for chronic kidney disease: evaluation, classification, and stratification. Am J Kidney Dis. 2002;39(2 suppl 1):S1-266.

22. Adelberg AM, Miller J, Doerzbacher M, Lambers DS. Correlation of quantitative protein measurements in 8, 12, and 24-h urine samples for the diagnosis of preeclampsia. Am J Obstet Gynecol. 2001;185:8047.

23. Evans W, Lensmeyer JP, Kirby RS, Malnory ME, Broekhuizen FF. Two-hour urine collection for evaluating renal function correlates with 24-h urine collection in pregnant patients. J Matern Fetal Med. 2000;9:233.

24. Somanathan N, Farrell T, Galimberti A. A comparison between 24-h and 2-h urine collection for the determination of proteinuria. $\mathrm{J}$ Obstet Gynaecol. 2003;23:378-80. 
25. Vassalotti JA, Stevens LA, Levey AS. Testing for chronic kidney disease: a position statement from the National Kidney Foundation. Am J Kidney Dis. 2007;50:169-80.

26. Brown MA, Lindheimer MD, De Swiet M, Van Assche A, Moutquin JM. The classification and diagnosis of hypertensive disorders of pregnancy: statement from the International Society for the
Study of Hypertension in Pregnancy (ISSHP). 2001;20:321-2.

Cite this article as: Devi LT, Nimonkar AR. Spot urinary albumin creatinine ratio as a predictor of preeclampsia and dilemma in clinical interpretation. Int J Reprod Contracept Obstet Gynecol 2018;7:4086-92. 